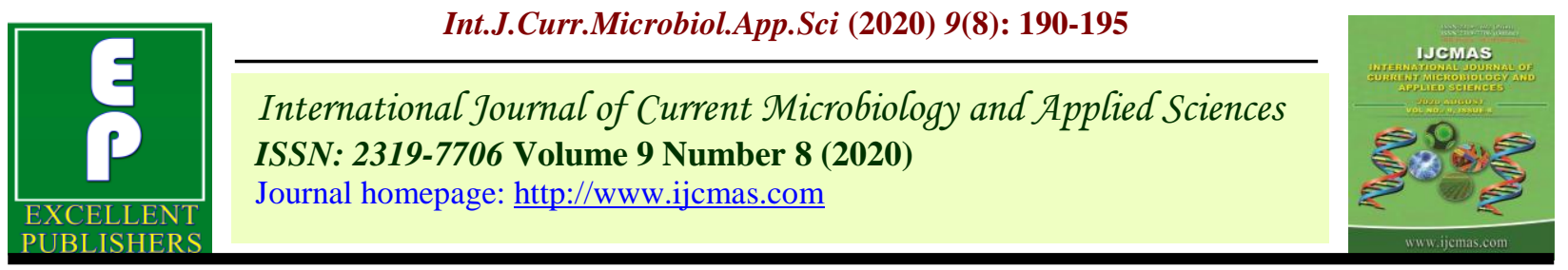

Original Research Article

https://doi.org/10.20546/ijcmas.2020.908.021

\title{
Effect of Watering Frequencies and Rehydration on Blood Parameters of Indigenous Sheep
}

\author{
M. Sahana*, R. J. Modi, M. M. Trivedi, M. M. Islam and K. N. Wadhwani \\ Department of Livestock Production Management, College of Veterinary Science and Animal \\ Husbandry, Anand Agricultural University, Anand - 388 001, Gujarat (INDIA) \\ *Corresponding author
}

\begin{abstract}
A B S T R A C T
Present experiment was conducted with the objective to study the effect of watering frequencies and rehydration on blood parameters of indigenous sheep under intensive production system during hot humid season. Eighteen adult dry non pregnant farm born Patanwadi and Marwari female $(25-35 \mathrm{~kg}$ ) sheep were divided randomly on body weight basis in three treatment groups viz., $\mathrm{T}_{1}$ : Control (watering thrice in a day), $\mathrm{T}_{2}$ : (watering twice in a day), $T_{3}$ : (watering once in a day). The duration of experiment was 44 days (42 days of different watering frequencies and 2 days of rehydration phase). The experimental animals were maintained on conventional feed as per the recommendations of ICAR feeding standard (2013). Once a day ad lib. watering $\left(\mathrm{T}_{3}\right)$ significantly $(\mathrm{P}<0.05)$ increased Haemoglobin $(\mathrm{g} / \mathrm{dL})$, PCV $(\%)$, urea $(\mathrm{mg} / \mathrm{dL})$, uric acid $(\mathrm{mg} / \mathrm{dL})$, creatinine $(\mathrm{mg} / \mathrm{dL})$ and $\mathrm{Na}(\mathrm{mmol} / \mathrm{L})$ due to haemoconcentration as compared to animals watered twice $\left(\mathrm{T}_{2}\right)$ or thrice a day $\left(\mathrm{T}_{1}\right)$. Moreover, rehydration significantly $(\mathrm{P}<0.05)$ influenced urea $(\mathrm{mg} / \mathrm{dL})$, uric acid $(\mathrm{mg} / \mathrm{dL})$ and $\mathrm{Na}(\mathrm{mmol} / \mathrm{L})$ levels in the blood.It may be concluded from present study that the adult sheep should be given $a d l i b$. water at least thrice a day at the interval of less than 12 hrs. in middle Gujarat agroclimatic condition during hot humid season.
\end{abstract}

Keywords

Watering

frequencies,

Rehydration, Blood

parameters, Sheep

Article Info

Accepted:

10 July 2020

Available Online:

10 August 2020

\section{Introduction}

Small ruminants are an integral part of farming systems in the arid and semi-arid regions of the world. These areas are characterized by fluctuating precipitation, water scarcity and unpredictable weather. Irregular rainfall of these areas leads to limited availability of water (Iniguez, 2005). Under water stress conditions, the transfer function of the kidney is altered (Kataria et al., 2007) which consequently increases the levels of urea and creatinine in blood (Igbokwe, 1993 and Jaber et al., 2004).

Water restriction in warm environment leads to increased haemoglobin level due to haemoconcentration ( $\mathrm{Li}$ et al., 2000). The study (Casamassima et al., 2008) carried out on water-restricted Comisana sheep revealed a significant increase of some blood metabolites like sodium, creatinine, urea and potassium. In this attempt, the present work was undertaken to investigate the selected 
blood parameters of indigenous sheep under intensive production system during hot humid season in response to different watering frequencies and rehydration.

\section{Materials and Methods}

The present experiment was conducted at Livestock Farm Complex, College of Veterinary Science and Animal Husbandry, Anand Agricultural University, Anand. Eighteen adult farm born dry non pregnant female Patanwadi and Marwari sheep (25-35 $\mathrm{kg}$ ) were selected as experimental animals and divided in to three treatment groups on the basis of body weight comprising six animals in each treatment viz., $\mathrm{T}_{1}$ : Control (watering thrice a day), $\mathrm{T}_{2}$ : (watering twice a day), $T_{3}$ : (watering once a day). The duration of experiment was 44 days (42 days of different watering frequencies and 2 days of rehydration phase) under intensive production system in hot humid season $\left(1^{\text {st }}\right.$ September to $15^{\text {th }}$ October). Animals of $\mathrm{T}_{1}$ group was offered water at 8.30 a.m., 2.30 p.m., and 8.30 p.m. whereas Group $\mathrm{T}_{2}$ at 8.30 a.m. and 8.30 p.m. and Group $\mathrm{T}_{3}$ at 8.30 a.m. only. The experimental animals were maintained on conventional feed as per the recommendations of ICAR feeding standard (2013). The blood samples were collected weekly once during different watering frequencies and daily in rehydration phase from the jugular vein under aseptic precaution in vacutainer with anticoagulant. The fresh whole blood was used to estimate hematological parameters like $\mathrm{Hb}$ and PCV using blood auto analyser (BC-2800 Vet, Mindray). The remaining blood was centrifuged for 30 minutes at 3000 rpm to separate plasma which was stored at $20 \quad{ }^{\circ} \mathrm{C}$ till further analysis. Various biochemical parameters like urea, uric acid, creatinine, sodium and potassium were estimated from plasma. Urea, uric acid and creatinine were analysed using chemistry analyser (BS-120, Mindray) while sodium and potassium were analysed using flame photometer 128.

\section{Statistical Analysis}

The experimental data were analysed using completely randomized design (Snedecor and Cochran, 1991).

\section{Results and Discussion}

Results of blood parameters of sheep under different watering frequencies and rehydration are presented in Table 1 and 2, respectively. The present study revealed a significant $(\mathrm{P}<0.05)$ increase in $\mathrm{Hb}$ level when animals maintained under watering once in a day as compared to twice $(4.14 \%)$ and thrice (4.39\%) a day groups, whereas animals of twice a day watering frequency was at par with thrice a day watering group. The Hb showed a non-significant reduction to the tune of 2.93 and $3.74 \%$ in $\mathrm{T}_{2}$ and $\mathrm{T}_{3}$, respectively after $48 \mathrm{hrs}$. of rehydration as compared to last week of different watering frequencies. The $72 \mathrm{hrs}$ watering interval (Adogla and Aganga, 2000) in goats and watering once in every three days in Awassi ewes (Hamadeh et al., 2006) elevated the $\mathrm{Hb}$ concentration are in accordance with present findings.

The experimental animals maintained on once a day watering showed significantly $(\mathrm{P}<0.05)$ higher PCV as compared to control group, whereas PCV of animals kept on twice a day watering was at par with thrice and once a day watering groups. The PCV of experimental animals increased by 1.28 and $4.53 \%$ in $\mathrm{T}_{2}$ and $\mathrm{T}_{3}$ groups, respectively as compared to control group. The elevation in $\mathrm{Hb}$ and PCV might be due to the development of haemoconcentration by consuming less water. The PCV decreased non-significantly to the tune of 3.33 and $4.97 \%$ in $\mathrm{T}_{2}$ and $\mathrm{T}_{3}$, respectively after $48 \mathrm{hrs}$. of rehydration as 
compared to last week of different watering frequencies. The PCV was significantly $(\mathrm{P}<0.05)$ higher in the experimental animals which maintained on $40 \%$ water restriction (Neelam, 2013 and Patel, 2015) supports the present findings. Abdelatif et al., (2010) also reported significant rise in PCV in dehydrated animals which returned to normal level after rehydration. The PCV values recovered nonsignificantly due to rehydration (Neelam, 2013) supports the current findings.

Table.1 Blood Parameters of sheep under different watering frequencies

\begin{tabular}{|c|c|c|c|}
\hline \multirow{2}{*}{ Blood Parameters } & \multicolumn{3}{|c|}{ Treatments } \\
\hline Haemoglobin (g/dL) & $\mathbf{T}_{\mathbf{1}}$ & $\mathbf{T}_{\mathbf{2}}$ & $\mathbf{T}_{\mathbf{3}}$ \\
\hline PCV (\%) & $8.78^{\mathrm{b}} \pm 0.07$ & $8.80^{\mathrm{b}} \pm 0.10$ & $9.16^{\mathrm{a}} \pm 0.12$ \\
\hline Urea (mg/dL) & $31.56^{\mathrm{b}} \pm 0.33$ & $31.97^{\mathrm{ab}} \pm 0.45$ & $32.99^{\mathrm{a}} \pm 0.30$ \\
\hline Uric acid (mg/dL) & $22.33^{\mathrm{b}} \pm 1.25$ & $23.64^{\mathrm{b}} \pm 1.60$ & $30.38^{\mathrm{a}} \pm 2.25$ \\
\hline Creatinine (mg/dL) & $0.38^{\mathrm{c}} \pm 0.01$ & $0.45^{\mathrm{b}} \pm 0.01$ & $0.51^{\mathrm{a}} \pm 0.02$ \\
\hline Sodium (mmol/L) & $1.62^{\mathrm{b}} \pm 0.04$ & $1.67^{\mathrm{ab}} \pm 0.03$ & $1.70^{\mathrm{a}} \pm 0.03$ \\
\hline Potassium (mmol/L) & $141.86^{\mathrm{c}} \pm 0.34$ & $145.54^{\mathrm{b}} \pm 0.62$ & $150.56^{\mathrm{a}} \pm 0.93$ \\
\hline
\end{tabular}

Means with dissimilar superscripts $(\mathrm{a}, \mathrm{b}, \mathrm{c})$ in a row differ significantly $(\mathrm{P}<0.05)$

Table.2 Blood Parameters of sheep under rehydration phase

\begin{tabular}{|c|c|c|c|c|}
\hline \multirow[b]{2}{*}{ Blood Parameters } & \multirow[t]{2}{*}{ Treatments } & \multirow{2}{*}{$\begin{array}{l}\text { Last week of different } \\
\text { watering frequencies }\end{array}$} & \multicolumn{2}{|c|}{ Rehydration phase } \\
\hline & & & $1^{\text {st }}$ day & $2^{\text {nd }}$ day \\
\hline \multirow[t]{3}{*}{ Haemoglobin $(\mathrm{g} / \mathrm{dL})$} & $\mathbf{T}_{1}$ & $8.95 \pm 0.16$ & $8.87 \pm 0.15$ & $8.90 \pm 0.17$ \\
\hline & $\mathbf{T}_{2}$ & $9.20 \pm 0.23$ & $9.05 \pm 0.22$ & $8.93 \pm 0.25$ \\
\hline & $\mathbf{T}_{3}$ & $9.63 \pm 0.39$ & $9.45 \pm 0.35$ & $9.27 \pm 0.35$ \\
\hline \multirow{3}{*}{$\begin{array}{c}\text { PCV } \\
(\%)\end{array}$} & $\mathbf{T}_{1}$ & $32.35 \pm 0.58$ & $32.08 \pm 0.65$ & $32.38 \pm 0.62$ \\
\hline & $\mathbf{T}_{2}$ & $33.00 \pm 1.14$ & $32.10 \pm 1.10$ & $31.90 \pm 1.02$ \\
\hline & $\mathbf{T}_{3}$ & $34.02 \pm 0.81$ & $32.80 \pm 0.89$ & $32.33 \pm 0.83$ \\
\hline \multirow{3}{*}{$\begin{array}{c}\text { Urea } \\
(\mathrm{mg} / \mathrm{dL})\end{array}$} & $\mathbf{T}_{1}$ & $19.87 \pm 1.92$ & $17.20 \pm 1.15$ & $18.71 \pm 1.28$ \\
\hline & $\mathbf{T}_{2}$ & $20.52^{\mathrm{a}} \pm 1.95$ & $12.15^{\mathbf{b}} \pm 0.54$ & $13.12^{b} \pm 0.56$ \\
\hline & $\mathbf{T}_{3}$ & $23.62^{\mathrm{a}} \pm 2.00$ & $15.48^{\mathrm{b}} \pm 1.44$ & $14.26^{\mathrm{b}} \pm 1.32$ \\
\hline \multirow{3}{*}{$\begin{array}{l}\text { Uric acid } \\
(\mathrm{mg} / \mathrm{dL})\end{array}$} & $\mathbf{T}_{1}$ & $0.42 \pm 0.04$ & $0.40 \pm 0.03$ & $0.41 \pm 0.04$ \\
\hline & $\mathbf{T}_{2}$ & $0.49^{\mathrm{a}} \pm 0.01$ & $0.37^{\mathbf{b}} \pm 0.02$ & $0.38^{\mathbf{b}} \pm 0.01$ \\
\hline & $\mathbf{T}_{3}$ & $0.55^{\mathrm{a}} \pm 0.02$ & $0.40^{\mathbf{b}} \pm 0.02$ & $0.41^{b} \pm 0.02$ \\
\hline \multirow{3}{*}{$\begin{array}{c}\text { Creatinine } \\
\text { (mg/dL) }\end{array}$} & $\mathbf{T}_{1}$ & $1.78 \pm 0.01$ & $1.78 \pm 0.01$ & $1.79 \pm 0.02$ \\
\hline & $\mathbf{T}_{2}$ & $1.79 \pm 0.01$ & $1.76 \pm 0.01$ & $1.76 \pm 0.01$ \\
\hline & $\mathbf{T}_{3}$ & $1.81 \pm 0.01$ & $1.79 \pm 0.01$ & $1.78 \pm 0.02$ \\
\hline \multirow{3}{*}{$\begin{array}{l}\text { Sodium } \\
(\mathrm{mmol} / \mathrm{L})\end{array}$} & $\mathbf{T}_{1}$ & $142.69 \pm 0.78$ & $142.05 \pm 0.98$ & $141.34 \pm 0.94$ \\
\hline & $\mathbf{T}_{2}$ & $148.36 \pm 1.68$ & $146.31 \pm 1.71$ & $144.79 \pm 1.80$ \\
\hline & $\mathbf{T}_{3}$ & $155.48^{a} \pm 0.75$ & $152.84^{\mathbf{b}} \pm 0.71$ & $149.30^{c} \pm 0.89$ \\
\hline \multirow[t]{3}{*}{ Potassium (mmol/L) } & $\mathbf{T}_{1}$ & $5.02 \pm 0.16$ & $4.99 \pm 0.14$ & $4.86 \pm 0.14$ \\
\hline & $\mathbf{T}_{2}$ & $5.16 \pm 0.19$ & $5.08 \pm 0.17$ & $4.71 \pm 0.09$ \\
\hline & $\mathbf{T}_{3}$ & $5.80 \pm 0.12$ & $5.72 \pm 0.12$ & $5.58 \pm 0.16$ \\
\hline
\end{tabular}

Means with dissimilar superscripts $(\mathrm{a}, \mathrm{b}, \mathrm{c})$ in a row within same treatment differ significantly $(\mathrm{P}<0.05)$ 
The urea concentration of sheep significantly $(\mathrm{P}<0.05)$ increased to the tune of 36.05 and $5.87 \%$ in $\mathrm{T}_{3}$ as compared to $\mathrm{T}_{1}$ and $\mathrm{T}_{2}$, respectively indicated adaptation of experimental animals to water restriction. The urea concentration of sheep in $\mathrm{T}_{2}$ group was at par with control group. The plasma urea concentration of experimental animals dropped down significantly $(\mathrm{P}<0.05)$ due to rehydration to the tune of 34.46 and $39.63 \%$ in the first and second day of rehydration, respectively as compared to last week of different watering frequencies. The water deprivation was associated with significant increase in urea $(\mathrm{mg} / \mathrm{dl})$ concentration (Alamer, 2006, Hamadeh et al., 2006, Kheir and Ahmed, 2008, Abdelatif et al., 2010, Neelam, 2013, Khanvilkar, 2014, Patel, 2015, Casamassima et al., 2016 and Patel, 2018) supports the present findings.

The uric acid concentration significantly $(\mathrm{P}<0.05)$ increased to the tune of 18.42 and $34.21 \%$ when experimental animals were subjected to 12 and 24 hrs. watering interval, respectively as compared to animals of control group, whereas uric acid concentration significantly $(\mathrm{P}<0.05)$ increased by $13.33 \%$ in $T_{3}$ as compared to $T_{2}$. The uric acid concentration dropped down significantly $(\mathrm{P}<0.05)$ in $\mathrm{T}_{2}(24.49$ and 22.45 $\%)$ and $\mathrm{T}_{3}(27.27$ and $25.45 \%)$ after 24 and 48 hrs. of rehydration as compared to last week of different watering frequencies. Khanvilkar (2014) and Patel (2018) reported significant $(\mathrm{P}<0.05)$ rise in uric acid concentration due to water deprivation supported the present findings.

The creatinine concentration increased significantly $(\mathrm{P}<0.05)$ to the tune of 3.09 and $4.94 \%$ when animals were offered water at 12 and $24 \mathrm{hrs}$ interval, respectively as compared to animals of control group. The effect of rehydration was non-significant. However, the creatinine concentration dropped down non-significantly by $1.66 \%$ in $\mathrm{T}_{2}$ and $\mathrm{T}_{3}$ groups after $48 \mathrm{hrs}$. of rehydration as compared to last week of different watering frequencies. According to Alamer (2006), Hamadeh et al., (2006), Abdelatif et al., (2010), Khanvilkar (2014), Casamassima et al., (2016) and Patel (2018) creatinine level increased significantly $(\mathrm{P}<0.05)$ on water restriction, which supports the present findings.

The plasma sodium level significantly $(\mathrm{P}<0.05)$ increased by 2.59 and $6.13 \%$ in $\mathrm{T}_{2}$ and $\mathrm{T}_{3}$, respectively as compared to the animals kept on thrice in a day watering frequency $\left(\mathrm{T}_{1}\right)$, whereas it increased significantly $(\mathrm{P}<0.05)$ by $3.45 \%$ in $\mathrm{T}_{3}$ in comparison to $\mathrm{T}_{2}$. The plasma sodium level of sheep maintained on $12 \mathrm{hrs}$. watering interval declined non-significantly to the tune of 1.38 and $2.41 \%$ on $1^{\text {st }}$ and $2^{\text {nd }}$ day of rehydration, respectively as compared to last week of different watering frequencies. The animals maintained on $24 \mathrm{hrs}$. watering interval showed significant $(\mathrm{P}<0.05)$ reduction in sodium level to the tune of 1.70 and $3.97 \%$ on $1^{\text {st }}$ and $2^{\text {nd }}$ day of rehydration, respectively as compared to last week of different watering frequencies, whereas the sodium level decreased significantly $(\mathrm{P}<0.05)$ by $2.28 \%$ in $\mathrm{T}_{3}$ group as compared to $\mathrm{T}_{2}$ group. The water restriction regimen resulted in a significant $(\mathrm{P}<0.05)$ increase in sodium level (Casamassima et al., 2008, Casamassima et al., 2016 and Patel, 2018) is in accordance with the present study.

The plasma potassium concentration (mmol/L) was not influenced by different watering frequencies. Potassium concentration decreased to the tune of 8.72 and $3.79 \%$ in $\mathrm{T}_{2}$ and $\mathrm{T}_{3}$ groups, respectively after $48 \mathrm{hrs}$. of rehydration as compared to last week of different watering frequencies. The non-significant effect of water deprivation (Igbokwe, 1993) and different 
watering frequencies (Patel, 2018) are in accordance with the present findings.

The study can be concluded that the adult sheep should be given ad libitum water at least thrice a day at the interval of less than 12 hrs. in middle Gujarat agroclimatic condition during hot humid season to sustain Uric acid $(\mathrm{mg} / \mathrm{dL})$ and Sodium (mmol/L) levels in blood. Water should not be withheld for more than 12 hrs. to sustain Haemoglobin $(\mathrm{g} / \mathrm{dL})$, PCV (\%), Urea (mg/dL) and Creatinine (mg/dL).

\section{References}

Abdelatif, A. M., Elsayed, S. A. and Hassan, Y. M. 2010. Effect of state of hydration on body weight, blood constituents and urine excretion in Nubian Goats (Capra hircus). World J. Agric. Sci., 6(2): 178188.

Adogla-Bessa, T. and Aganga, A. A. 2000. Responses of Tswana goats to various lengths of water deprivation. S. Afri. J. Anim. Sci., 30(1): 87-91.

Alamer, M. 2006. Physiological responses of Saudi Arabia indigenous goat to water deprivation. J. Small Ruminant Research, 63: 100-109.

Casamassima, D., Pizzo, R., Palazzo, M., D'Alessandro, A. G. and Martemucci, G. 2008. Effect of water restriction on productive performance and blood parameters in Comisana sheep reared under intensive condition. Small Ruminant Research, 78: 69-175.

Casamassima, D., Vizzarri, F., Nardoia, M. and Palazzo, M. 2016. The effect of water-restriction on various physiological variables in intensively reared Lacaune ewes. VeterinarniMedicina, 61(11): 623-634.

Hamadeh, S. K., Rawda, N., Jaber, L. S., Habre, A., Abi-Said, M. and Barbour, E. K. 2006. Physiological responses to water restriction in dry and lactating Awassi ewes. Livestock Science, 101(13): 101-109.

ICAR, 2013. Nutrient requirements of Livestock and Poultry. Indian Council of Agricultural Research, New Delhi, India.

Igbokwe, I. O. 1993. Haemoconcentration in Yankasa sheep exposed to prolonged water deprivation. Small Ruminant Research, 12(1): 99-105.

Iniguez, L. 2005. Small ruminant breeds in West Asia and North Africa. ICARDA Caravan Issue 22. [Online] Available: http://www.icarda.org/ Publications/ Caravan/ Caravan22/ Focus_3.htm [2012 Dec. 22].

Jaber, L. S., Habre, A., Rawda, N., AbiSaid, M., Barbour, E. K. and Hamadeh, S. K. 2004. The effect of water restriction on certain physiological parameters in Awassi sheep. Small. Rumin. Res., 54: 115-120.

Kataria, N., Kataria, A. K., Agarwal, V. K., Garg, S. L. and Sahni, M. S. 2007. Solute loads and transfer function of kidney in dromedary camel during dehydration and rehydration in winter and summer. Vet. Arh., 77: 327-246.

Khanvilkar, A. V. 2014. Effect of Water Restriction and Rehydration on Sheep and Goats under Middle Gujarat Agroclimatic Condition. Thesis presented to Anand Agriculture University, Anand, Gujarat State.

Kheir, I. M. and Ahmed, M. M. M. 2008. Effects of water and feed restriction on some physiological and haematological parameters and blood constituents of Sudanese desert goats fed high- and low-quality forages under semi-arid conditions. Indian J. Anim. Res., 42(1): $39-43$.

Li, B. T., Christopherson, R. J. and Cosgrove, S. J. 2000. Effect of water restriction and environmental temperatures on 
metabolic rate and physiological parameters in sheep.Can. J. Anim. Sci., 80: 97-104.

Neelam, G. (2013). Performance of indigenous sheep under water restriction and rehydration in Middle Gujarat Agroclimatic condition. Thesis presented to Anand Agriculture University, Anand, Gujarat State.

Patel, N. R. 2015. Performance of indigenous sheep under water restriction and rehydration in Agroclimatic condition of middle Gujarat. Thesis presented to
Anand Agriculture University, Anand, Gujarat State.

Patel, R. P. 2018. Performance of indigenous sheep under water deprivation and rehydration. Thesis presented to Anand Agriculture University, Anand, Gujarat State.

Snedecor, G. W. and Cochran, W. G. 1991. Statistical methods $\left(7^{\text {th }}\right.$ ed.). The Iowa State University Press, Ames. Iowa, USA.

\section{How to cite this article:}

Sahana, M., R. J. Modi, M. M. Trivedi, M. M. Islam and Wadhwani, K. N. 2020. Effect of Watering Frequencies and Rehydration on Blood Parameters of Indigenous Sheep. Int.J.Curr.Microbiol.App.Sci. 9(08): 190-195. doi: https://doi.org/10.20546/ijcmas.2020.908.021 